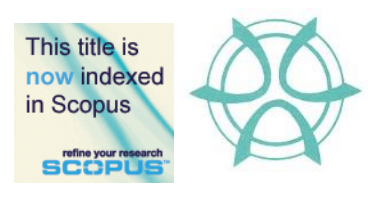

\title{
A REVIEW ON THE NEEDS TO IMPROVE MALAYSIAN TREE PRESERVATION ORDER (TPO) (ACT 172)
}

\author{
Nik Adlin Nik Mohamed Sukri ${ }^{1}$, Noriah Othman ${ }^{2}$, \& Wan Tarmeze Wan \\ Ariffin $^{3}$ \\ ${ }^{1,2}$ Faculty of Architecture, Planning and Surveying \\ UNIVERSITI TEKNOLOGI MARA \\ ${ }^{3}$ Development Projects Team \\ FOREST RESEARCH INSTITUTE MALAYSIA
}

\begin{abstract}
Trees are important to human and the environment, and should always be protected to continuously benefit us. The Malaysian government, recognising that the rapid development of the country has put trees at risks of being damaged and killed, thus introduced Tree Preservation Order (Act 172) in 1996. However, recently, there have been cases whereby trees that were meant to be preserved were felled down without consent of the local authorities. This situation has raised questions on the effectiveness of the tree protection legislation. This paper gives information on the progress of the TPO (Act 172) gathered through literature review and proposes improvements of the legislation.
\end{abstract}

Keyword: Tree Preservation Order (TPO), Town and Country Planning Act 1976, Act 172

Date Received: $2^{\text {nd }}$ August 2017

Date of Acceptance: $6^{\text {th }}$ November 2017 
Nik Adlin Nik Mohamed Sukri, Noriah Othman, \& Wan Tarmeze Wan Ariffin

A Review On the Needs to Improve Malaysian Tree Preservation Order (TPO) (Act 172)

\section{INTRODUCTION}

Trees give the environment and human endless benefits. They provide oxygen, improve air quality, conserve water, preserve soil and support wildlife. Because trees are important part of every community, especially in the urban area, it is critical that trees in urban settings such as at parks, road sides and buildings are preserved (retained) and sustainably managed. For a developing country such as Malaysia, which in 2016 its construction projects was estimated to reach RM83 billion (Kaur, 2015), the need to preserve trees becomes more pertinent due to the rapid development of the country. Forested areas need to be preserved from being indiscriminately cleared for urban development purposes.

Realising this fact, Malaysia has introduced the Tree Preservation Order (TPO) under the Town and Country Planning Act 1976 (Act 172) (Malaysia) that would protect the trees that are meant to be preserved from being damaged or killed. However, there were two recent cases of old and large trees being felled down in the name of development that have raised questions whether or not the TPO has been effectively implemented. In the first case, as reported by Bernama (2015), a property development company would face a fine of RM 966,000.00 for cutting down 19 trees of more than 30 years at Melaka Raya a month before. Less than a year after that, a contractor was ordered by DBKL to pay RM $300,000.00$ as a penalty for chopping down 16 rain trees along Jalan Cochrane in March 2016 (Fined RM 300,000 for felling rain trees, 2016).

In both cases, the concerns over the tree felling were also shared by organizations related to historical conservation such as the Malacca Historical City Council (MBMB) and Ecotourism and Conservation Society Malaysia. In the second case, it was reported that the residents living in the area were horrified to find only stumps left of what were once magnificent trees at the site. Thus, this raised the question of whether the city councils were really serious or indiscriminate in taking care of old and protected trees. Were there similar cases that we do not know?

This paper aims to inform on the progress of the TPO (Act 172) since its inception. It also elaborates on what needs to be done to make this legislation more effectively enforced by looking at the TPOs of other countries.

\section{TREE PRESERVATION ORDER (TPO) OF OTHER COUNTRIES}

According to Department of Communities and Local Government of UK (DCLG, 2012b), Tree Preservation (also Protection or Retention) Order (also Policy or By-Law) or TPO, is a written order made by a local planning authority which, in general, makes it an offence to cut down, top, lop, uproot, wilfully damage or wilfully destroy a tree protected by that order without the authority's permission. Its purpose is to protect trees which bring significant amenity benefit to the local area (Nicholson, 2016). This protection is particularly important where trees are under threat. 
PLANNING MALAYSIA

Journal of the Malaysia Institute of Planners (2017)

In a TPO related publication by the Leichhardt Municipal Council of Australia (LMC) (2001), it is mentioned that unless the Council gives written consent for specific works, it is prohibited to ring bark, cut down, lop, top, remove, injure or wilfully destruct any tree in the Leichhardt Local Government Area. The publication further states that while the TPO is aimed at conserving and enhancing tree cover and general landscaping of Leichhardt, it will also conserve and enhance the ecological, climatic, amenity, aesthetic, economic and cultural values of the area.

Types of tree to be preserved and protected are different from one country to another. A TPO adopted by a City of Canada Bay Council (CCBC) (2006) defines preserved trees as those with the following properties - height of $4 \mathrm{~m}$ or more, trunk girth of $500 \mathrm{~mm}$ and bigger (at any point), and the tree is a cycad or mangrove irrespective of its dimensions. In Northampton Borough Council, all types of tree can be protected except hedges, bushes or shrubs (Wright, 2010). The Blue Mountains City Council in Australia elaborates that all trees are protected but gives a list of exempted trees which includes the trees which are proven dead or which could pose an imminent danger to property or life by the authorities (BMCC, 2012).

The pertinent remarks of each of the TPO related publication reviewed above are highlighted and summarised in Table 1.

Table 1 Remarks of TPO in other Countries

\begin{tabular}{|c|c|c|}
\hline No. & Publication & Remarks \\
\hline 1 & DCLG (2012b) & $\begin{array}{l}\text { General definition: TPO is to prevent cutting down, } \\
\text { topping, lopping, uprooting, wilfully damaging or } \\
\text { destroying protected trees. }\end{array}$ \\
\hline 2 & Nicholson (2016) & $\begin{array}{l}\text { Trees to be preserved are including: } \\
\text { - } \quad \text { trees that benefit the local area } \\
\text { - } \quad \text { trees under threat }\end{array}$ \\
\hline 3 & LMC (2001) & $\begin{array}{l}\text { Any tree in the Leichhardt Local Government Area } \\
\text { shall not be damaged (cut down, etc.) without a } \\
\text { written consent of the Council }\end{array}$ \\
\hline 4 & CCBC (2006) & $\begin{array}{l}\text { Preserved trees are defined as: } \\
\text { - } \quad \text { trees with height } \geq 4 \mathrm{~m} \\
\text { - } \quad \text { trees with trunk girth } \geq 500 \mathrm{~mm} \\
\text { - } \quad \text { cycad (regardless of size) } \\
\text { - } \quad \text { mangrove (regardless of size) }\end{array}$ \\
\hline 5 & Wright (2010) & $\begin{array}{l}\text { All types of tree can be protected except hedges, } \\
\text { bushes or shrubs. }\end{array}$ \\
\hline 6 & BMCC (2012) & $\begin{array}{l}\text { The local authorities shall provide a list of trees } \\
\text { exempted from preservation which includes the } \\
\text { proven dead and hazardous trees. }\end{array}$ \\
\hline
\end{tabular}


Nik Adlin Nik Mohamed Sukri, Noriah Othman, \& Wan Tarmeze Wan Ariffin

A Review On the Needs to Improve Malaysian Tree Preservation Order (TPO) (Act 172)

\section{CONTINUOUS EVALUATION OF TPO IN OTHER COUNTRIES}

Recently, the Australian Capital Territory (ACT) government amended its Tree Protection Act (TPA) 2005 effective from 21 June 2016. About six months before, an editorial in the Canberra Times (Tree Regulation Needs Reviewing, 2015) urges the review of Tree Protection Act and citing that the ACT chapter of the Australian Institute of Architects had long been asking for the review to avoid unnecessary delays and increased costs to housing projects. In April 2012, the British Government published new regulations cancelling the provisions in the TPOs issued before 6 April 2012 and replaced them with the provisions of the same year's The Town and Country Planning (Tree Preservation) (England) Regulations 2012.

The moves by the Australian and the British governments mentioned above reveal that as with other Acts or Legislation, TPO is not a static document, and it should be subjected to continuous reviewing and evaluation to improve and expand its contents as well as its implementation and enforcement. Reports of evaluation by the professionals, consultants and academicians are meant to be presented to the government officials who have the power to bring forward suggestions and make the amendments.

Examples of such reports or consultation papers are those by Jessop (2002) for the Scottish Government; FitzGibbon \& Summers (2002) for Southern Ontaria governance, Canada; and Brown et al. (2016) for the Town of Concord, a municipal in the state of Massachusetts, USA. The responses from government and authorities are as in documents by One Scotland (2010), the Department of Community \& Local Government in London (DCLG) (2012a) and Waverley Council in Australia (WC) (2013).

Among the Scottish TPO aspects that need improvement as reported by Jessop (2002) are the non-existent or the very low standard of management at many local TPO sites which could be caused by a combination of a lack of knowledge, finance and commitment to the maintenance of protected trees and a distinct lack of up-to-date government advice on TPOs with regard to procedures and technical standards. He further compared the situation with that in England where 'Tree Preservation Orders: A Guide to the Law and Good Practice', produced by Department of the Environment, Transport and Regions (DETR) in 2000, provides a very effective coverage of the key issues, something that Scotland could follow.

FitzGibbon \& Summers (2002) reveals the fact that many municipalities within the studied area do not have tree by-laws (equivalent to TPOs) and many others do not actively enforce their tree by-laws. This situation has caused significant forested areas in Southern Ontario left unprotected. The report also concludes that the lack of a stop work order within the tree by-laws passed under the Forestry Act limits the ability of by-law enforcement officers to protect trees during improper cutting. Many trees may be cut during the time of offence 
PLANNING MALAYSIA

Journal of the Malaysia Institute of Planners (2017)

awareness and the actual charges being laid. The inability of tree by-law officers to issue tickets under the Forestry Act limits their ability to immediately impact upon a situation of illegal cutting. It also forces them to undertake the more arduous task of laying charges involving a court hearing.

Furthermore, the report mentions that while the by-law under the Forestry Act can be effectively enforced, it is not efficiently enforced. A great level of effort and finances are required to convict offenders. Many councillors or members of the judiciary are unaware of the importance of the tree by-law, thus they do not support stringent enforcement. The influence of politics and economics can take precedence over environmental concerns. Finally, while the level of expertise of tree by-law officers has increased there is no formalized training for tree by-law officers.

Brown et al. (2016), after analysing the implementation of tree by-laws (TPOs) in four neighbouring towns, suggest that the Town of Concord should have TPO which includes the following elements. First, it must have as a specific and clear 'trigger' such as a demolition permit for an existing residence or a building permit for expansion of $>50 \%$ footprint. Next, the TPO requires a tree survey and is based on setbacks (similar to zoning), which is important for wildlife corridors and streetscape aesthetics, and attempts to preclude the major cause for concern, i.e., clear cutting of lots for development. Moreover, the TPO should have a provision for a tree fund if on-site replacement is not feasible. Last but not least, it should also include penalties sufficiently high as to deter noncompliance.

\section{GUIDELINES FOR TREE PRESERVATION ORDER}

Legislation, such as the TPO should be accompanied by efforts to guide the people to understand what are required by the legislation so that it can be effectively enforced and complied with. The guidance can be done in many ways such as awareness campaigns and trainings. The guidance materials given-out during the campaigns or to support the trainings can be in the forms of guidelines, manuals and legislative interpretation notes.

In developed countries such as the UK, Australia and the USA, there are already many guidance materials available to help the local authorities interpret the TPO legislative requirements, to understand the definitions and terms, and to develop the procedures for the implementation and enforcement of the TPO. Examples of such TPO legislative interpretation guidelines and notes are DCLG (2012b), City of Richmond (CR) (2016) and District of Saanich (DS) (2015).

Another type of guidelines is the more technical, with step-by-step tree protection procedures and illustrations to be followed by the construction industry, are plenty and can be downloaded easily from the internet from various sources abroad. Among the illustrative documents are Stirling Council (SC) (2003), Devon County Council (DCC) (2006), City of Edinburgh (CE) (2007), 
Nik Adlin Nik Mohamed Sukri, Noriah Othman, \& Wan Tarmeze Wan Ariffin

A Review On the Needs to Improve Malaysian Tree Preservation Order (TPO) (Act 172)

Oregon State University (OSU Extension Service) (2009) and NYC Parks \& Recreation (NYCPR) (2009).

\section{MALAYSIAN TREE PRESERVATION ORDER (ACT 172)}

TPO in Malaysia was established in 1995 when Part VA entitled 'Tree Preservation Order' was added to the Town and Country Planning Act 1976 (Act 172). In the layman's terms, the TPO enables local planning authorities to prohibit the cutting down, topping, lopping, uprooting, damaging or destroying of trees that are meant to be preserved and to prosecute the offences with a fine not exceeding one hundred thousand ringgit (RM100,000) or an imprisonment for a term not exceeding six (6) months, or both. Felled trees should be replaced according to time and place determined by the local planning authority. Examples of trees to be preserved are such as those planted by the local authorities, trees that have historical values and trees of endangered species, regardless of their sizes.

The TPO (Act 172) also states that, by default, all trees with girth exceeding 0.8 meter are meant to be preserved and they are not allowed to be fell unless the trees are dying, posing imminent danger or the felling is required to comply with other legal regulations. In all the cases, the felling of preserved trees must have written permission by the local authorities.

The TPO (Act 172) is already three decades old, thus should have been implemented or enforced very well to have positive impacts on national agenda of greening the environment. However, according to Nor Hanisah \& Hitchmough (2015), the progress of TPO (Act 172) has been unsatisfactory since its launching due to problems like funding, staffing, and people's perception.

\section{Early Days of the TPO (Act 172)}

The commencement of the TPO (Act 172) was initially applauded and has drawn a lot of attention among those attending the Workshop on Tree Management in Urban Areas in Malaysia held at FRIM in December 1996. The participants were those whose jobs are related to or affected by trees such as landscape architects, contractors and researchers and also the people from municipalities and private nurseries (Philip, 1997).

About three years after that, the TPO (Act 172) was again mentioned in a report by the Economic Planning Unit (EPU) (2002) on a study for the sustainable development of the highlands of Peninsular Malaysia. The report, in its Chapter 6 emphasises on the enforcement of the TPO (Act 172) by local planning authorities to prevent the rampant clearing of trees in local authority areas. 
PLANNING MALAYSIA

Journal of the Malaysia Institute of Planners (2017)

\section{Enforcement and Implementation Status of the TPO (Act 172)}

A decade after the launching, Malaysians began reviewing the effectiveness of the TPO (Act 172), and the early comments were not favourable. Sharifah Zubaidah (2006), perhaps being raged by the felling of an old and huge Jati tree (Tectona grandis) to make way for new quarters for government health workers near the Penang Hospital, has mocked the TPO (Act 172) as 'teeth without the bite' to reflect its ineffectiveness especially in the enforcement aspect.

Another disappointing remark on the TPO (Act 172) collectively came from a larger group of professionals, i.e., the Construction Industry Development Board (CIDB). In its publication Strategic Recommendation for Improving Environmental Practices in Construction Industry, CIDB (2007) clearly states that the enforcement of Tree Preservation Order (Act 172) was not satisfactory and that Selangor was the only state to take action to gazette the tree preservation order and prevent certain trees from being felled. The report also stated that TPO (Act 172) has yet to be adopted by other states and suggest that it is adopted and enforced uniformly in all states of Malaysia. CIDB also recommends that the State Governments and the Ministry of Housing and Local Government to work towards increasing the awareness and enforcement among local authorities regarding the TPO (Act 172).

The National Landscape Department (JLN) (2011) in the National Landscape Policy has put up a strategy that enables it to re-evaluate and formulate landscape related legislation with several action plans including to strengthen the enforcement of the TPO (Act 172).

\section{Academic Research Containing the TPO (Act 172)}

Malaysian scholars have also included the TPO (Act 172) as the subject matters of their research. For example, Rafiuddin (2011) evaluates the adoption and implementation of the TPO (Act 172) by the Kuala Lumpur City Hall (DBKL) through interviews with personnel from various departments within the City Hall. The thesis finding too highlights on the lack of implementation of the TPO (Act 172), even though legal provision has already existed to support the whole management and practices process. Nor Akmal et al. (2011), in analysing the status of urban greenspace policy, planning, and management in Malaysia, have included knowledge on TPO (Act 172) as one of the questions asked in the expert interviews with municipal officers in selected cities. Meanwhile, Raziah (2013), reports that one of the interview respondents has suggested that in the context of landscape conservation, the Department of National Heritage of Malaysia needs to specify the conservation and preservation means for the National Heritage Act comparable to the functions of TPO (Act 172) in the Town Planning Act. Intan Afida and Halimaton Saadiah (2014) conducted a preliminary review on disaster risk reduction agendas incorporated in development plans and reports in Malaysian urban planning practice namely the National Physical Plan (NPP), the 
Nik Adlin Nik Mohamed Sukri, Noriah Othman, \& Wan Tarmeze Wan Ariffin

A Review On the Needs to Improve Malaysian Tree Preservation Order (TPO) (Act 172)

State Structure Plan (SSP), the Local Plan (LP), the Special Area Plan (SAP) and the Development Proposal Report (DPR). For the DPR stage, TPO (Act 172) is mentioned as the disaster risk reduction agenda to be adopted when assessing the conditions of vegetation in the existing site.

Nor Hanisah and Hitchmough (2015) compared the perceptions among landscape professionals' on tree retention and legislation which also include the TPO (Act 172). The study concludes that in the landscape professionals section, the disparities of responses between the landscape architects and town planners are notable. Issues such as legislation and practical; and tree biology were tested among the landscape professionals. The most significant results were gathered from the monetary issue on preserving trees, their understanding of the TPO (Act 172) and their knowledge on tree biology. When further questions were asked to the landscape professionals on the tree root biology, very few of the landscape architects could answer the questions right. Knowledge about tree root system and structure are lacking among the landscape architects and they have to undertake in-house training for the enrichment of their knowledge.

Wan Noor Anira et al. (2016), in their study to introduce and promote the characteristics of heritage trees in Taiping Lake Garden to the community, used the TPO (Act 172) to justify and support their research efforts. Ramly, Noriah and Raziah (2016) analysed the implementation of TPO (Act 172) in tree management practice through interview and survey. The results show that $80 \%$ of the respondents considered the TPO (Act 172) were not fully utilized during landscape design stage.

\section{Summary of the TPO (Act 172) Literature Review}

All the TPO (Act 172) related literatures reviewed above are summarized in Table 2. It provides proofs that Malaysian TPO (Act 172) is still far from perfect and should be reviewed, re-evaluated and improved from time to time to ensure its purpose of greening the country is achieved.

Table 2 The TPO (ACT 172) Related Publications

\begin{tabular}{|c|c|c|}
\hline No. & Publication & Remarks on TPO (Act 172) \\
\hline 1 & $\begin{array}{l}\text { Town and Country } \\
\text { Planning Act 1976: } \\
\text { Revision } 1995\end{array}$ & Inclusion of Tree Preservation Order (TPO). \\
\hline 2 & Philip (1997) & Applause and praise of the TPO (Act 172). \\
\hline 3 & EPU (2002) & $\begin{array}{l}\text { Emphasising the enforcement of the TPO (Act 172) } \\
\text { by local planning authorities. }\end{array}$ \\
\hline 4 & $\begin{array}{l}\text { Sharifah Zubaidah } \\
\text { (2006) }\end{array}$ & TPO (Act 172) is 'teeth without the bite'. \\
\hline 5 & CIDB (2007) & $\begin{array}{l}\text { Expressing dissatisfaction over the enforcement of the } \\
\text { TPO (Act 172) by local authorities. }\end{array}$ \\
\hline
\end{tabular}


6

JLN (2011)

$7 \quad$ Rafiuddin (2011)

8 Nor Akmal et al. (2011)

$9 \quad$ Raziah (2013)

Intan Afida \&

10 Halimaton Saadiah (2014)

11 Nor Hanisah \& Hitchmough (2015)

12 Wan Noor Anira et al. (2016)

13 Ramly, Noriah \& Raziah (2016)
Strategy 6.1. Re-evaluate and Formulate Legislation Related to Landscape (including the TPO (Act 172)). Highlighting the lack of the TPO (Act 172) implementation within KL City Hall. Questioning the knowledge of TPO (Act 172) among the greenspace municipal officers.

Revealing a suggestion that TPO (act 172)-like means should be included in the National Heritage Act to enhance landscape preservation.

TPO (Act 172) as the disaster risk reduction agenda to be adopted in Development Proposal Report when assessing the conditions of vegetation in the existing site.

Disclosing the fact that knowledge about tree root system and structure are lacking among the landscape architects.

Using the TPO (Act 172) to justify the efforts to save heritage trees in Taiping.

Reporting that $80 \%$ of the respondents considered the TPO were not fully utilized during proposed landscape design.

\section{CONCLUSION}

TPO has been enforced and implemented in many developed countries as ways to protect trees, especially those that are meant to be preserved. Furthermore, most of the countries have also reviewed and revised their TPO from time to time to make it more effective. They have also had guidelines for TPO. Malaysian TPO (Act 172), introduced more than two decades ago, has not made much progress in term of its implementation and enforcement. This fact was also loudly voiced up by a Malaysian public figure, i.e., Tun Jeanne Abdullah, the chairman of Landskap Malaysia (an NGO she established in 2009) who urges the authorities to enhance the implementation of TPO (Act 172) and forcing the developers to replace the trees that were cut for development projects.

No doubt, as that of other countries, Malaysian TPO (Act 172) also needs constant reviews and further revisions. Additionally, a guidelines to help parties understand the TPO (Act 172) better is also required. However, such guidance materials that is solely dedicated to the TPO (Act 172) is not forthcoming. The State of Selangor in its planning guidelines and standards has included the implementation of sub-section 35A(1) of the TPO (Act 172) and enforcement of the TPO guidelines without further guidance for tree protection on construction sites (JPBDS, 2010). Thus, it is imperative for the relevant authorities to quickly publish a set of guidelines to help other parties understand and implement TPO (Act 172) effectively. 
Nik Adlin Nik Mohamed Sukri, Noriah Othman, \& Wan Tarmeze Wan Ariffin

A Review On the Needs to Improve Malaysian Tree Preservation Order (TPO) (Act 172)

\section{REFERENCES}

Bernama (2015, April 18). Developer slapped with almost million-ringgit fine for felling 30-year-old trees in Malacca. Malay Mail. Retrieved from www.themalaymailonline.com

Blue Mountains City Council [BMCC] (2012). Tree Preservation Order (Local Environmental Plan 1991). Blue Mountains City Council, Australia.

Brown, E., Collins, C., Gailus T. B., Funkhouser, E., Hire, G. M., Muno, T., Meltzer, R., Lodynsky, L., Cash, B. W., \& Hughes, E. (2016). Tree preservation subcommittee report to planning board. TreePS.

City of Canada Bay Council [CCBC] (2006). Tree Preservation Order Policy. City of Canada Bay Council.

City of Edinburgh [CE] (2007). Tree technical manual: standards and specifications. Planning \& Zoning Department. City of Edinburgh.

City of Richmond [CR] (2016). Tree Protection Bylaw 8057. City of Richmond.

Construction Industry Development Board [CIDB] (2007). Strategic recommendations for improving environmental practices in construction industry. Lembaga Pembangunan Industri Pembinaan Malaysia.

Department of Community \& Local Government [DCLG] (2012a). Tree preservation orders: proposals for streamlining - government response to the consultation. Department for Communities and Local Government, London.

Department of Community \& Local Government [DCLG] (2012b). Protected Trees. A Guide to Tree Preservation Procedures. Department for Communities and Local Government, London.

District of Saanich [DS] (2015). Tree Protection Bylaw No.9272. District of Saanich.

Devon County Council [DCC] (2006). Tree protection and new development guidance note. Environment, Economy \& Culture Directorate, Devon County Council.

Economic Planning Unit [EPU] (2002). Study for the sustainable development of the highlands of peninsular Malaysia - final report volume II. Prime Minister's Department, Malaysia.

Fined RM 300,000 for felling rain trees (2016, March 28). The Star Online. Retrieved from www.thestar.com.my.

FitzGibbon, J., \& Summers, S. (2002). Report on tree conservation by-laws in Southern Ontario. School of Rural Planning and Development, University of Guelph.

Kaur, G. (2015). Construction sector to be busy in 2016 with projects worth RM83bil. The Star. Retrieved from www.thestar.com.my

Intan Afida M.A. \& Halimaton Saadiah H. (2014). Disaster risk reduction in Malaysian urban planning. Planning Malaysia. 12, 35-58. 
PLANNING MALAYSIA

Journal of the Malaysia Institute of Planners (2017)

JPBD Selangor (2010). Manual Garispanduan \& Piawaian Perancangan Negeri Selangor. Edisi kedua. Jabatan Perancangan Bandar dan Desa Negeri Selangor.

Jessop, R. (2002). The effectiveness of tree preservation orders in Scotland. Scottish Executive Social Research.

Leichhardt Municipal Council [LMC] (2001). Tree Preservation Order. Leichhardt Municipal Council, Australia.

National Landscape Department [JLN] (2011). National Landscape Policy. Kementerian Perumahan dan Kerajaan Tempatan.

Nicholson, R. (2016). Trees protection matters. RICS Building Surveying Journal. July/August 2016, 22-23.

Nor Akmal, A. A., Konijnendijk, C. C., Sreetheran, M., \& Nilsson, K. (2011). Greenspace planning and management in Klang Valley, Peninsular Malaysia. Arboriculture \& Urban Forestry, 37(3), 99-107.

Nor Hanisah, M. H. \& Hitchmough, J. D. (2015). The comparison of perceptions among landscape professionals' on tree retention and legislation. International Academic Research Journal of Social Science, 1(2), 164176.

NYC Parks \& Recreation [NYCPR] (2009). Parks tree preservation protocols. City of New York Parks \& Recreation.

One Scotland (2010). Tree preservation orders (TPOS): Analysis of consultation responses. Scottish Government.

Oregon State University [OSU] Extension Service (2009). Tree protection on construction and development sites: A best management practices guidebook for the Pacific Northwest. Oregon State University.

Philip, E. (1997). Workshop on tree management in urban areas in Malaysia. PROSEA Newsletter, No. 18, April 1997.

Rafiuddin, R. (2011). Urban tree management: Towards best practices and applications (Master thesis). Universiti Teknologi MARA, Malaysia.

Ramly H, Noriah O., \& Raziah A. (2016). Tree Preservation Order and its role in enhancing the quality of life. Procedia-Social and Behavioral Sciences, 222, 493-501.

Raziah, A. (2013). Cultural landscapes as heritage in Malaysia: Potentials, threats \& current practices. Delft, Netherlands: Eburon Academics Publisher.

Stirling Council [SC] (2003). Protecting and managing trees on development sites: Development advice note. Stirling Council.

Sharifah Zubaidah, S. A. K. (2006). Tree Preservation Orders Under Malaysian Planning Law: Teeth Without The Bite. Malaysian Institute of Planners' Buletin Perancang, February 2006, 10 \& 18.

Tree Protection Act 2005 (Australian Capital Territory). 
Nik Adlin Nik Mohamed Sukri, Noriah Othman, \& Wan Tarmeze Wan Ariffin

A Review On the Needs to Improve Malaysian Tree Preservation Order (TPO) (Act 172)

Tree Regulation Needs Reviewing (2015, December 5). The Canberra Times Online. Retrieved from www.canberratimes.com.au.

Town and Country Planning Act 1976 (Act 172) (Malaysia).

Town and Country Planning (Tree Preservation) (England) Regulations 2012.

Wan Noor Anira W.A, Norasikin H, Khalilah H \& Nadiyanti M.N (2016). The morphology of heritage trees in colonial town: Taiping Lake Garden, Perak, Malaysia. Procedia - Social and Behavioral Sciences, 222, 621630.

Waverley Council [WC] (2013). Tree Management Policy. Waverley Council.

Wright, L. (2010). Tree protection - a guidance leaflet on new and existing tree preservation orders. Northampton Borough Council. 